\title{
MASTERPLAN SISTEM PENGELOLAAN AIR LIMBAH DOMESTIK DI WILAYAH PERKOTAAN KABUPATEN SUKOHARJO
}

\author{
Wiharyanto Oktiawan, Nurandani Hardyanti, Poerborini Damayanti
}

Departemen Teknik Lingkungan, Fakultas Teknik, Universitas Diponegoro

\begin{abstract}
Abstrak
Di Indonesia, air limbah domestik merupakan pencemar terbesar yang masuk ke badan air. Pemantauan dan pengendalian air buangan dapat dilakukan salah satunya dengan meningkatkan pelayanan dalam hal sanitasi. Pemerintah menetapkan target terhadap tahun 2015-2019 antara lain 100\% capaian pelayanan akses air minum, 0\% proporsi rumah tangga yang menempati hunian dan permukiman tidak layak (kumuh) di kawasan perkotaan dan $100 \%$ capaian pelayanan akses sanitasi. Perencanaan masterplan ini bertujuan untuk menyediakan fasilitas sanitasi yang memadai dalam pengelolaan air limbah domestik terutama di wilayah perkotaan Kabupaten Sukoharjo. Masterplan ini akan mengkaji aspek teknis-teknologis dalam perencanaan pengelolaan air limbah domestik. Pada masterplan ini direncanakan akan dibangun 3 buah IPAL skala perkotaan dan 8 buah IPAL skala permukiman besar yang akan melayani $20 \%$ penduduk perkotaan Kabupaten Sukoharjo. IPAL skala perkotaan direncanakan terdapat 2 buah di Kecamatan Grogol dan 1 buah di Kecamatan Kartasura. IPAL skala permukiman besar direncanakan terletak di Kecamatan Kartasura, Kecamatan Gatak, 2 buah di Kecamatan Baki, masing-masing 1 buah di Kecamatan Bendosari, Gatak, Polokarto dan Kecamatan Sukoharjo. Selain itu, untuk pelayanan sistem setempat direncanakan 3 (tiga) daerah pelayanan IPLT yang dibangun secara bertahap. Tahap pertama yaitu optimalisasi IPLT Eksisting (IPLT Mojorejo), tahap kedua yaitu pembangunan IPLT di Desa Bekonang Kecamatan Mojolaban, dan tahap ketiga pembangunan IPLT di Desa Grajegan Kecamatan Tawangsari. IPLT direncanakan dapat melayani sekitar $70 \%$ penduduk perkotaan.
\end{abstract}

Kata kunci: air limbah domestik; grey water; Kabupaten Sukoharjo; masterplan

\begin{abstract}
In Indonesia, domestic wastewater is the largest water pollutant. Monitoring and controlling of wastewater can be done by improving services in terms of sanitation. The government's targets for 2015-2019 are 100\% achievement of access to drinking water services, 0\% proportion of inhabited and inadequate housing (slum) in urban areas and 100\% achievement of sanitation access services. This masterplan aims to provide adequate sanitation facilities in domestic wastewater management, especially in urban areas in Sukoharjo Regency. This Masterplan will examine the technical-technological aspects of domestic wastewater management. This masterplan is planned to build 3 urban scale Waste Water Treatment Plant (WWTP) and 8 large-scale WWTP that will serve $20 \%$ of the urban population of Sukoharjo Regency. Urban scale WWTPs are planned to be located in Grogol and Kartasura District. Large scale WWTPs are planned to be located in Kartasura, Gatak, Baki, Bendosari, Gatak, Polokarto and Sukoharjo District. In addition, for local system services, Faecal Sludge Treatment Plant service areas will be developed in 3 stages. The first stage is the optimization of Existing FSTP (IPLT Mojorejo), the second stage is the development of FSTP in Mojolaban District, and the third stage is the development of FSTP in Tawangsari District. This Faecal Sludge Treatment Plant is planned to serve approximately $70 \%$ of the urban population of Sukoharjo Regency.
\end{abstract}

Keywords : domestic wastewater; grey water; masterplan; Sukoharjo Regency 


\section{Pendahuluan}

Seiring dengan pesatnya pertumbuhan jumlah penduduk, pemakaian air bersih juga mengalami peningkatan yang berakibat pada meningkatnya jumlah air limbah yang dapat mencemari lingkungan. Pada beberapa tahun terakhir, tingkat polusi di badan air seperti sungai, danau, dan pantai akibat buangan limbah domestik semakin tinggi. Pemantauan dan pengendalian air buangan dapat dilakukan salah satunya dengan meningkatkan pelayanan dalam hal sanitasi. Data dari Dinas Kesehatan Kabupaten Sukoharjo tahun 2017 menunjukkan jumlah buang air besar sembarangan atau BABs sebesar $1,54 \%$. Jumlah BABs mendekati $0 \%$ menyatakan bahwa tingkat kesadaran masyarakat Kabupaten Sukoharjo terkait dengan sanitasi dan kesehatan cukup tinggi. Kesadaran masyarakat akan sanitasi harus didukung dengan adanya fasilitas sanitasi atau pengelolaan air limbah yang memadai. Namun, hasil pengukuran kualitas air sungai dibeberapa sungai Kabupaten Sukoharjo berdasarkan SLHD tahun 2017 menunjukkan bahwa masih banyak sungai di Kabupaten Sukoharjo yang kualitasnya di bawah baku mutu. Hal ini disebabkan masih tercemarnya sungai oleh air limbah, baik air limbah domestik maupun air limbah industri karena belum adanya sistem pengelolaan air limbah yang relevan dengan kondisi Kabupaten Sukoharjo saat ini.

Menurut RTRW Kabupaten Sukoharjo Tahun 2010-2031, Kabupaten Sukoharjo dibagi menjadi 2 wilayah, yaitu wilayah perkotaan dan perdesaan. Wilayah perkotaan memiliki jumlah dan kepadatan penduduk yang lebih tinggi dibandingkan wilayah perdesaan, sehingga dapat dikatakan bahwa daerah perkotaan Kabupaten Sukoharjo lebih membutuhkan rancangan pengelolaan air limbah domestik yang memadai. Terkait dengan permasalahan tersebut, diperlukan rancangan masterplan sistem pengelolaan air limbah domestik di wilayah perkotaan Kabupaten Sukoharjo.

Masterplan atau Rencana Induk merupakan suatu dokumen perencanaan dasar yang menyeluruh mengenai pengembangan sistem Prasarana dan Sarana Air Limbah untuk periode 20 (dua puluh) tahun. Periode perencanaan dalam penyusunan Rencana Induk dibagi menjadi 3 (tiga) tahap perencanaan, perencanaan jangka panjang, jangka menengah, dan jangka pendek. Sistem Pengelolaan Air
Limbah Domestik terbagi menjadi dua sistem pengelolaan, yaitu Sistem Pengelolaan Air Limbah Domestik Setempat (SPALD-S) dan Sistem Pengelolaan Air Limbah Domestik Terpusat (SPALD-T). Pemilihan jenis Sistem Pengelolaan Air Limbah Domestik (SPALD) dilaksanakan dengan mempertimbangkan kepadatan penduduk, kedalaman muka air tanah, kemiringan tanah, permeabilitas tanah, dan kemampuan pembiayaan (Kementrian PUPR 2017).

Sistem Pengelolaan Air Limbah Domestik SPALD Setempat (SPALD-S) adalah sistem pengelolaan yang dilakukan dengan mengolah air limbah domestik di lokasi sumber, yang selanjutnya lumpur hasil olahan diangkut dengan sarana pengangkut ke Sub-sistem Pengolahan Lumpur Tinja. Komponen SPALD-S terdiri atas sub-sistem pengelolaan setempat, sub-sistem pengangkutan, dan sub-sistem pengolahan lumpur tinja. SPALD Terpusat yang selanjutnya disebut SPALD-T adalah sistem pengelolaan yang dilakukan dengan mengalirkan air limbah domestik dari sumber secara kolektif ke Sub-sistem Pengolahan Terpusat untuk diolah sebelum dibuang ke badan air permukaaan. Cakupan pelayanan SPALD$\mathrm{T}$ terdiri atas skala perkotaan, skala permukiman, dan skala kawasan tertentu. Komponen SPALD-T terdiri dari atas sub sistem pelayanan, sub sistem pengumpulan dan sub sistem pengolahan terpusat (Kementrian PUPR 2017).

Untuk menyusun skala prioritas pelayanan pengelolaan air limbah domestik suatu Kabupaten perlu dilakukan dengan pembobotan dan pemetaan wilayah perencanaan pelayanan air limbah untuk tiap desa/kelurahan di Kabupaten Sukoharjo. Perencanaan dilakukan pada beberapa sektor penunjang, antara lain pembobotan dan mapping berdasarkan Angka Kepadatan Penduduk, berdasarkan Beban Pencemaran/Angka BOD, berdasarkan Angka Kondisi Sanitasi, dan berdasarkan Angka Kesakitan/Penyakit. Sedangkan dalam pemilihan teknologi pengolahan air limbah domestik mempertimbangkan faktor kepadatan, kondisi kawasan, sumber air yang digunakan, kedalaman muka air, nilai permeabilitas tanah, kondisi kemiringan yang ada, ketersediaan lahan, dan kemampuan membayar masyarakat (Kementerian PUPR 2016). Alternatif lokasi IPAL sebagai teknologi pengolahan air 
limbah domestik dipertimbangkan dengan beberapa faktor diantaranya penduduk yang akan dilayani, jarak antara lokasi IPAL dengan pusat kota dan pemukiman, kemiringan lokasi IPAL, jenis tanah pada lahan yang tersedia, tata guna lahan yang telah tertera pada RTRW, badan air penerima, bahaya banjir, legalitas dari lahan yang akan diperuntukan untuk IPAL, dan batas administrasi wilayah (Departemen Pekerjaan Umum 2006). Sehingga dapat ditentukan daerah pelayanan, zona prioritas, opsi jenis teknologi yang akan digunakan serta alternatif lokasi IPAL yang memungkinkan.

\section{Metodologi}

Tahap pelaksanaan perencanaan sistem pengelolaan air limbah dimulai dengan analisis wilayah perencanaan yang meliputi identifikasi daerah yang akan dilayani, pembagian zona pelayanan, dan penentuan zona prioritas. Kabupaten Sukoharjo terdiri dari wilayah perkotaan dan wilayah perdesaan, wilayah tersebut kemudian akan dinilai dan dianalisis untuk menentukan zona pelayanan dan zona prioritas. Kemudian pembagian zona pelayanan SPALD di Kabupaten Sukoharjo ditetapkan berdasarkan 6 kriteria, yaitu Keseragaman Jumlah Penduduk Perkotaan, Keseragaman Luas Permukiman Perkotaan, Keseragaman Tingkat Kepadatan Penduduk di Permukiman Perkotaan., Keseragaman Tingkat Topogragi/Kemiringan, dan Keseragaman Tingkat BABs. Pemilihan zona prioritas dilakukan pada beberapa sektor penunjang, antara lain pembobotan dan mapping berdasarkan Angka Kepadatan Penduduk, berdasarkan Beban Pencemaran/Angka BOD, berdasarkan Angka Kondisi Sanitasi, dan berdasarkan Angka Kesakitan/Penyakit.

Pemilihan teknologi pengolahan air limbah domestik mempertimbangkan faktor kepadatan penduduk, kedalaman muka air tanah, kemiringan tanah, permeabilitas tanah, dan kemampuan pembiayaan masyarakat. Sedangkan pemilihan alternative lokasi IPAL mempertimbangkan, penduduk yang akan dilayani, jarak antara lokasi IPAL dengan pusat kota dan pemukiman, kemiringan lokasi IPAL, jenis tanah pada lahan yang tersedia, tata guna lahan yang telah tertera pada RTRW, badan air penerima, bahaya banjir, legalitas dari lahan yang akan diperuntukan untuk IPAL, dan batas administrasi wilayah.
Tahap selanjutnya dalam penyusunan masterplan sistem pengelolaan air limbah domestik adalah evaluasi kondisi eksisting sistem pengelolaan air limbah domestic di Kabupaten Sukoharjo. Setelah dilakukan evaluasi, muncul beberapa altematif penyaluran dan pelayanan pengolahan air limbah, kemudian ditentukan altematif terpilih.

\section{Hasil dan Pembahasan}

Pengelolaan air limbah domestik di Kabupaten Sukoharjo berprinsip pada 5 aspek yaitu aspek pengaturan, kelembagaan, keuangan, peran serata masyarakat/swasta/perguruan tinggi dan teknis teknologis. Namun, perencanaan masterplan sistem pengelolaan air limbah domestik Kabupaten Sukoharjo ini akan berfokus pada aspek teknis-teknologis. Dalam aspek pengaturan, Kabupaten Sukoharjo belum memiliki peraturan khusus terkait pembuangan air limbah domestik.

Dalam aspek kelembagaan, Pemerintah Kabupaten Sukoharjo memiliki instansi yang berperan khusus untuk menangani pengelolaan air limbah. Instansi Pemerintah Kabupaten Sukoharjo yang menangani dan terkait dalam pengelolaan air limbah domestik yaitu Dinas Pekerjaan Umum dan Penataan Ruang Kabupaten Sukoharjo (Bidang Cipta Karya) dan Dinas Perumahan dan Kawasan Permukiman Bidang Cipta Karya Seksi Air Minum dan Penyehatan Lingkungan, Dinas Lingkungan hidup bidang Pengendalian, Pencemaran dan Kerusakan Lingkungan Hidup Seksi Pemantauan Lingkungan Hidup dan Kerusakan Lingkungan, serta Dinas Perumahan Dan Kawasan Permukiman Bidang Perumahan Seksi Pengelolaan Rumah Susun.

Dalam aspek keuangan, anggaran untuk pengelolaan air limbah khususnya untuk limbah domestik belum terdata dengan baik, sehingga besaran untuk setiap kegiatan kurang dapat dipahami, seperti untuk anggaran perawatan dan operasional IPLT, penyedotan tinja, monitoring dan evaluasi IPAL Permukiman terbangun dan sebagainya. Kemudian, alokasi pendanaan pemerintah daerah terbatas, sehingga tidak dapat memenuhi kebutuhan tingginya biaya investasi sistem pengelolaaan air limbah terpusat dan kemampuan masyarakat dalam membayar biaya berlanggan SPALD rendah.

Dalam aspek peran serta masyarakat, permasalahan yang dihadapi yaitu persepsi 
dari sebagian masyarakat bahwa sarana sanitasi khususnya terkait air limbah domestik belum menjadi kebutuhan yang mendesak dan pengetahuan masyarakat terkait pengelolaan air limbah domestik, khususnya tangki septik yang memenuhi standart masih rendah.

Dalam hal aspek teknis-teknologis, Kabupaten Sukoharjo belum memiliki SPALD-T skala perkotaan dan skala kawasan tertentu, dan telah memiliki 29 unit IPAL yang melayani sekitar 1,1\% masyarakat Kabupaten Sukoharjo. Sedangkan dalam hal SPALD-S, tingkat kepemilikan JSP di Kabupaten Sukoharjo adalah 86,37 \%, JSSP adalah 8,37\% , penggunaan jamban bersama atau sharing adalah $3,72 \%$ dan tingkat BABs sebesar $1,54 \%$. Pelayanan skala komunal yang ada di Kabupaten Sukoharjo berupa MCK umum dan MCK ++. Terdapat 8 unit MCK ++ yang melayani $687 \mathrm{KK}$ atau sekitar $0,39 \%$ dari seluruh penduduk Kabupaten Sukoharjo. Kabupaten Sukoharjo memiliki satu unit IPLT yang bertempat satu lokasi dengan TPA Kabupaten Sukoharjo di Desa Mojorejo Kecamatan Bendosari, namun belum adanya peraturan terkait retribusi pengangkutan lumpur tinja menyebabkan pengoperasian IPLT yang kurang optimal.

Penilaian zona prioritas terbagi menjadi 3 ketegori yaitu baik, sedang, dan buruk. Kondisi dengan kategori baik merupakan daerah dengan kondisi sanitasi yang cukup baik dan masuk ke dalam rencana jangka panjang. Sedangkan kategori sedang merupakan daerah dengan kondisi sanitasi yang harus diperhatikan, karena jika tidak akan berubah menjadi buruk. Sedangkan untuk kategori buruk menandakan bahwa kondisi sanitasi di wilayah tersebut buruk dan masuk kedalam program jangka pendek.

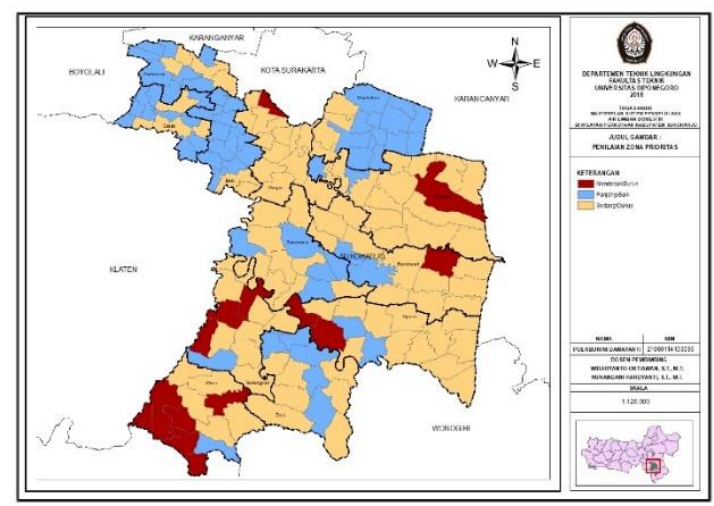

Gambar 1. Hasil Penilaian Zona Prioritas Kabupaten Sukoharjo

Berdasarkan penilaian arahan pengembangan jenis SPALD didapat 3 jenis SPALD yang akan digunakan di
Kabupaten Sukoharjo, yaitu SPALD-T Perkotaan, SPALD-T Permukiman, dan SPALD-S Skala Kawasan. Arahan pengembangan teknologi pengelolaan air limbah yang didapatkan tidak seluruhnya dapat diterapkan pada lokasi desa/kelurahan terpilih. Desa yang menurut penilaian menggunakan teknologi SPALD-T Skala Permukiman, tidak seluruhnya akan menggunakan teknologi SPALD-T Skala Permukiman, namun hanya sebagian saja sedangkan masyarakat sisanya masih menggunakan Sistem Setempat.

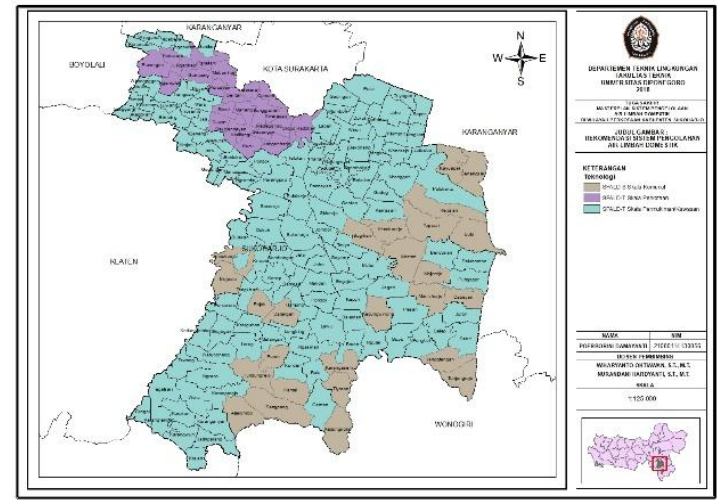

Gambar 2. Hasil Penilaian Rekomendasi SPALD Kabupaten Sukoharjo

Dalam pelayanan pengelolaan air limbah domestik, daerah di Kabupaten Sukoharjo dibagi menjadi 3 zona yang memiliki rencana target masing-masing.

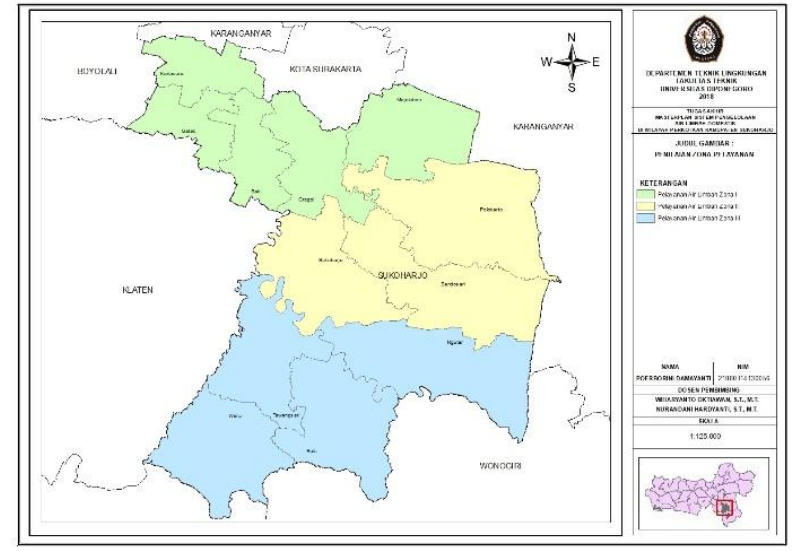

Gambar 3. Hasil Penilaian Zona Pelayanan Kabupaten Sukoharjo

\section{Sistem Pengolahan Air Limbah Domestik Setempat}

Perencanaan untuk SPALD-Setempat skala individual di seluruh bangunan atau rumah yang tidak terlayani oleh sistem terpusat, dan juga SPALD-Setempat skala komunal. Sedangkan, skala komunal diperuntukkan untuk 2 (dua) sampai dengan 10 (sepuluh) unit rumah tinggal dan Mandi Cuci Kakus (MCK), dapat berupa permanen dan non permanen (mobile 
toilet). Perencanaan sarana sanitasi yang dapat melayani 2-10 unit rumah dapat berupa tangki septik komunal. Untuk pengembangan SPALD-Setempat Skala Komunal dengan tangki septik komunal direncanakan pada daerah dengan kepadatan tinggi dan pada masyarakat yang memiliki tingkat ekonomi rendah, dan juga pada daerah kumuh.

Tabel 1. Lokasi Perencanaan SPALD-S Komunal

\begin{tabular}{|c|c|c|}
\hline No. & Kecamatan & Desa \\
\hline 1. & Grogol & $\begin{array}{l}\text { Banaran } \\
\text { Sanggrahan } \\
\text { Kadokan } \\
\text { Pondok } \\
\text { Grogol }\end{array}$ \\
\hline 2. & Kartasura & $\begin{array}{l}\text { Kartasura } \\
\text { Gumpang } \\
\text { Makamhaji } \\
\text { Pucangan }\end{array}$ \\
\hline 3. & Sukoharjo & $\begin{array}{l}\text { Sonorejo } \\
\text { Jetis } \\
\text { Bulakan } \\
\text { Sukoharjo } \\
\text { Begajah } \\
\text { Bulakrejo } \\
\text { Kenep } \\
\text { Kriwen } \\
\text { Dukuh }\end{array}$ \\
\hline 4. & Gatak & $\begin{array}{l}\text { Blimbing } \\
\text { Kagokan } \\
\text { Klaseman } \\
\text { Luwang } \\
\text { Sanggung } \\
\text { Tempel } \\
\text { Trangsan } \\
\text { Wironanggan }\end{array}$ \\
\hline 5. & Mojolaban & $\begin{array}{l}\text { Cangkol } \\
\text { Plumbon } \\
\text { Dukuh }\end{array}$ \\
\hline 6. & Baki & $\begin{array}{l}\text { Mancasan } \\
\text { Gedongan }\end{array}$ \\
\hline
\end{tabular}

Untuk peningkatan pelayanan pada sistem setempat, pada pengangkutan lumpur tinja maka dilakukan penambahan armada pengangkut berupa truk dan motor roda tiga penyedot tinja. Dalam pengolahan lumpur tinja, dikembangkan menjadi 3 (tiga) daerah pelayanan IPLT yang dibangun secara bertahap. Tahap pertama yaitu optimalisasi IPLT Eksisting (IPLT Mojorejo), tahap kedua yaitu pembangunan IPLT di Desa Bekonang Kecamatan Mojolaban, dan tahap ketiga pembangunan IPLT di Desa Grajegan Kecamatan Tawangsari. IPLT direncanakan dapat melayani sekitar $70 \%$ penduduk perkotaan.

\section{Sistem Pengolahan Air Limbah Domestik Terpusat}

Ada 3 jenis sistem penyaluran air limbah domestik terpusat yang bisa diterapkan yaitu perkotaan, kawasan tertentu, dan permukiman.
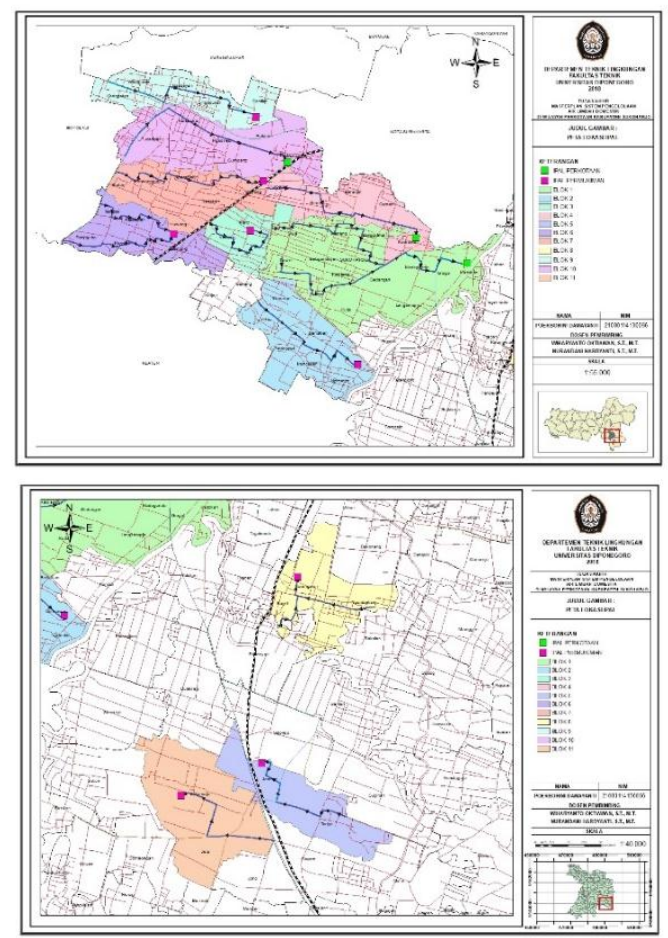

Gambar 4. Peta Lokasi Perencanaan IPAL

Sistem wilayah perkotaan merupakan suatu opsi jenis layanan penyaluran air limbah domestik berskala besar dengan melayani rumah atau bangunan dengan jumlah penghuni melebihi 20.000 jiwa. Sistem perkotaan direncanakan menyalurkan air limbah kakus maupun air bekas cucian, masak, dan kamar mandi. Pada wilayah perkotaan Kabupaten Sukoharjo direncanakan tiga unit IPAL skala perkotaan. 
Tabel 2. Rencana Pengembangan SPALD-T Skala Perkotaan

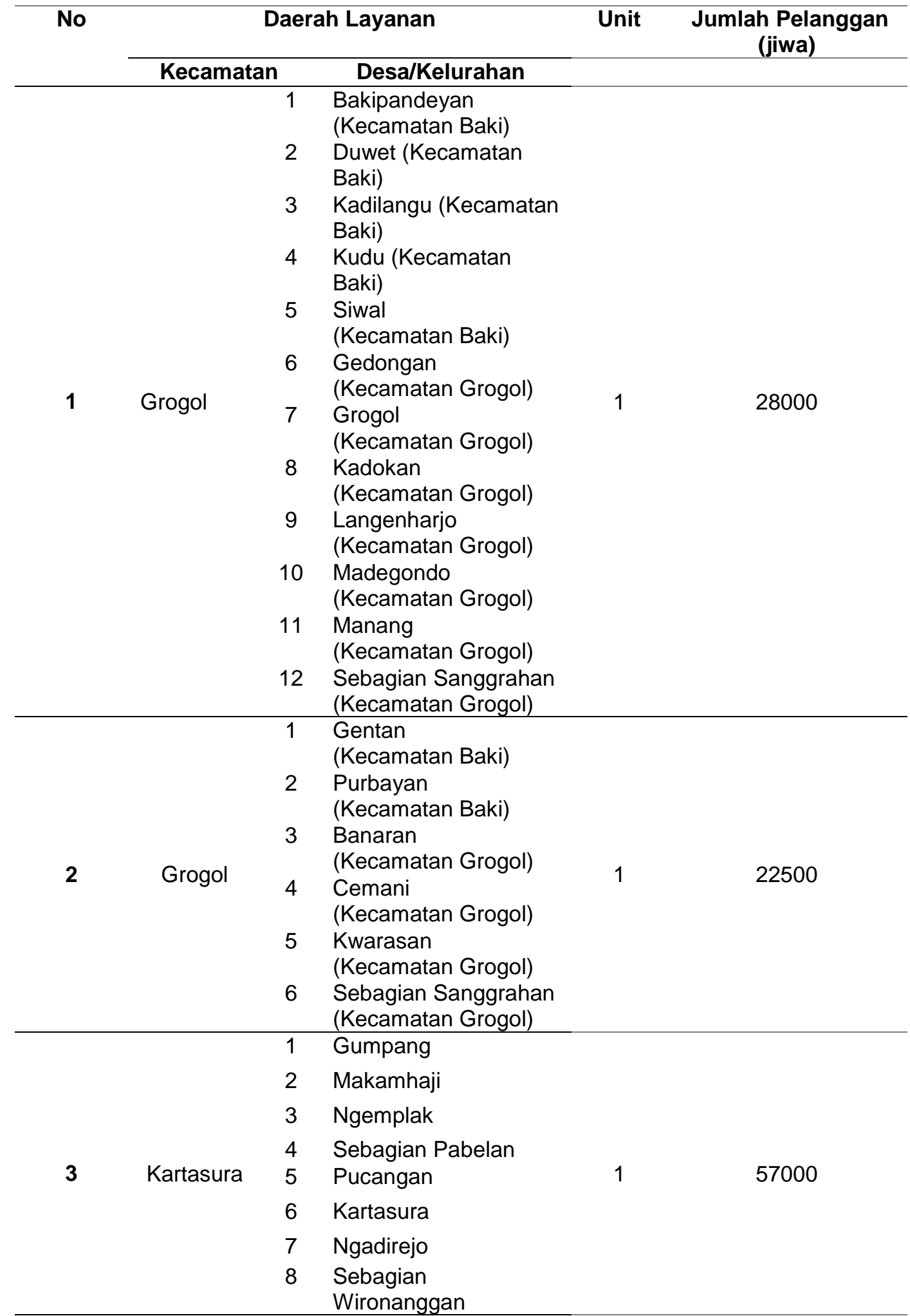

Sistem terpusat permukiman merupakan suatu opsi jenis layanan saluran air limbah dengan jumlah penngguna dibawah 20.000 jiwa. Adapun pembangunan IPAL skala permukiman dibagi menjadi skala permukiman besar dan kecil. Direncanakan akan dibangun 8 buah IPAL skala permukiman besar. IPAL skala permukiman besar terdapat di Kecamatan Bendosari, Kecamatan Grogol, Kecamatan Mojolaban, Kecamatan Polokarto, Kecamatan Nguter, Kecamatan Sukoharjo dan Kecamatan Tawangsari. 
Rencana pembangunan IPAL skala permukiman dibagi menjadi 4 waktu per 5 tahun, yaitu tahun 2018-2022, tahun 2023-
2027, tahun 2028-2032, dan tahun 20322037.

Tabel 3. Rencana Pengembangan SPALD-T Skala Permukiman Tahun 2018-2022

\begin{tabular}{|c|c|c|c|c|c|}
\hline \multirow[t]{2}{*}{ No } & \multicolumn{3}{|c|}{ Daerah Layanan } & \multirow[t]{2}{*}{ Unit } & \multirow{2}{*}{$\begin{array}{c}\text { Jumlah } \\
\text { Pelanggan (jiwa) }\end{array}$} \\
\hline & Kecamatan & & Desa/Kelurahan & & \\
\hline 1 & Bendosari & 1 & Gentan & 1 & 400 \\
\hline \multirow[t]{2}{*}{2} & Grogol & 1 & Pondok & 1 & 400 \\
\hline & & 2 & Telukan & 1 & 1000 \\
\hline \multirow[t]{4}{*}{3} & Mojolaban & 1 & Laban & 1 & 800 \\
\hline & & 2 & Palur & 1 & 400 \\
\hline & & 3 & Plumbon & 1 & 400 \\
\hline & & 4 & Tegalmade & 1 & 800 \\
\hline \multirow[t]{2}{*}{4} & Nguter & 1 & Baran & 1 & 400 \\
\hline & & 2 & Kepuh & 1 & 400 \\
\hline \multirow[t]{2}{*}{5} & Polokarto & 1 & Jatisobo & 1 & 400 \\
\hline & & 2 & Mranggen & 1 & 400 \\
\hline \multirow[t]{3}{*}{6} & Sukoharjo & 1 & Banmati & 1 & 400 \\
\hline & & 2 & Begajah & 1 & 400 \\
\hline & & 3 & Kriwen & 1 & 400 \\
\hline 7 & Tawangsari & 1 & Lorog & 1 & 600 \\
\hline
\end{tabular}

Tabel 4. Rencana Pengembangan SPALD-T Skala Permukiman Tahun 2023-2027

\begin{tabular}{|c|c|c|c|c|c|}
\hline \multirow[t]{2}{*}{ No } & \multicolumn{3}{|c|}{ Daerah Layanan } & \multirow[t]{2}{*}{ Unit } & \multirow{2}{*}{$\begin{array}{c}\text { Jumlah } \\
\text { Pelanggan (jiwa) }\end{array}$} \\
\hline & Kecamatan & & Desa/Kelurahan & & \\
\hline 1 & Bendosari & 1 & Sidorejo & 1 & 400 \\
\hline \multirow[t]{2}{*}{2} & Bulu & 1 & Bulu & 1 & 400 \\
\hline & & 2 & Kunden & 1 & 400 \\
\hline 3 & Grogol & 1 & Pandeyan & 1 & 400 \\
\hline \multirow[t]{4}{*}{4} & Mojolaban & 1 & Gadingan & 1 & 400 \\
\hline & & 2 & Kragilan & 1 & 400 \\
\hline & & 3 & Sapen & 1 & 400 \\
\hline & & 4 & Wirun & 1 & 400 \\
\hline \multirow[t]{2}{*}{5} & Nguter & 1 & Daleman & 1 & 400 \\
\hline & & 2 & Pondok & 1 & 400 \\
\hline \multirow[t]{3}{*}{6} & Polokarto & 1 & Bakalan & 1 & 400 \\
\hline & & 2 & Kemasan & 1 & 400 \\
\hline & & 3 & Wonorejo & 1 & 400 \\
\hline 7 & Sukoharjo & 1 & Sonorejo & 1 & 400 \\
\hline 8 & Tawangsari & 1 & Keteguhan & 1 & 400 \\
\hline 9 & Weru & 1 & Jatingarang & 1 & 800 \\
\hline
\end{tabular}

Tabel 5. Rencana Pengembangan SPALD-T Skala Permukiman Tahun 2027-2032

\begin{tabular}{|c|c|c|c|c|c|}
\hline \multirow[t]{2}{*}{ No } & \multicolumn{3}{|c|}{ Daerah Layanan } & \multirow[t]{2}{*}{ Unit } & \multirow[t]{2}{*}{ Jumlah Pelanggan (jiwa) } \\
\hline & Kecamatan & & esa/Kelurahan & & \\
\hline \multirow[t]{4}{*}{1} & Bulu & 1 & Gentan & 1 & 400 \\
\hline & & 2 & Lengking & 1 & 400 \\
\hline & & 3 & Malangan & 1 & 400 \\
\hline & & 4 & Ngasinan & 1 & 400 \\
\hline \multirow[t]{2}{*}{2} & Gatak & 1 & Geneng & 1 & 400 \\
\hline & & 2 & $\begin{array}{l}\text { Mayang, Sraten, } \\
\text { Trangsan, } \\
\text { sebagian } \\
\text { Wironanggan, }\end{array}$ & 1 & 13.500 \\
\hline
\end{tabular}




\begin{tabular}{|c|c|c|c|c|c|}
\hline \multirow[t]{2}{*}{ No } & \multicolumn{3}{|c|}{ Daerah Layanan } & \multirow[t]{2}{*}{ Unit } & \multirow[t]{2}{*}{ Jumlah Pelanggan (jiwa) } \\
\hline & Kecamatan & & Desa/Kelurahan & & \\
\hline & & & sebagian & & \\
\hline & & & Ngemplak & & \\
\hline & & & (Kecamatan & & \\
\hline & & & $\begin{array}{l}\text { Kartasura), } \\
\text { sebaqian Luwang }\end{array}$ & & \\
\hline & & 3 & Krajan & 1 & 400 \\
\hline 3 & Grogol & 1 & Parangjoro & 1 & 400 \\
\hline \multirow[t]{6}{*}{4} & Kartasura & 1 & Gonilan, & 1 & 17.500 \\
\hline & & & Kertonatan, & & \\
\hline & & & Ngabeyan, & & \\
\hline & & & Singopuran, & & \\
\hline & & & Wirogunan, dan & & \\
\hline & & & sebagian Pabelan & & \\
\hline \multirow[t]{4}{*}{5} & Mojolaban & 1 & Cangkol & 1 & 400 \\
\hline & & 2 & Dukuh & 1 & 400 \\
\hline & & 3 & Joho & 1 & 400 \\
\hline & & 4 & Klumprit & 1 & 400 \\
\hline 6 & Nguter & 1 & Nguter & 1 & 400 \\
\hline 7 & Polokarto & 1 & Godog & 1 & 400 \\
\hline \multirow[t]{2}{*}{8} & Sukoharjo & 1 & Bulakrejo & 1 & 400 \\
\hline & & 2 & Gayam & 1 & 1.000 \\
\hline \multirow{3}{*}{9} & Weru & 1 & Karanganyar & 1 & 400 \\
\hline & & 2 & Ngreco & 1 & 800 \\
\hline & & 3 & Weru & 1 & 400 \\
\hline
\end{tabular}

Pada rencana pengembangan SPALD$\mathrm{T}$ skala permukiman tahun 2028-2032 terdapat 2 IPAL permukiman skala besar, yaitu di Kecamatan Kartasura dan Kecamatan Gatak. Lokasi IPAL Permukiman skala besar di Kecamatan Gatak diletakkan di Desa Mayang dengan elevasi sekitar $111 \mathrm{mdpl}$ dengan daerah pelayanan di Kecamatan Gatak dan Kecamatan Kartasura. Daerah yang akan dilayani oleh lokasi IPAL Permukiman Mayang pada Desa Mayang, Sraten, Trangsan, sebagian Wironanggan, sebagian Ngemplak (Kecamatan Kartasura), sebagian Luwang. Elevasi pada ujung daerah pelayanan adalah sekitar 133 mdpl.

Lokasi IPAL Permukiman skala besar di Kecamatan Kartasura dapat di tempatkan di Desa Gonilan dengan elevasi sekitar 114 mdpl dengan seluruh daerah pelayanan berlokasi di Kecamatan Kartasura. Daerah yang akan dilayani oleh Lokasi IPAL Permukiman Gonilan adalah Desa Gonilan, Kertonatan, Ngabeyan, Singopuran, Wirogunan, dan sebagian Pabelan. Elevasi pada ujung daerah pelayanan adalah sekitar $148 \mathrm{mdpl}$, maka penyaluran air limbah dapat dilakukan secara gravitasi.

Tabel 6. Rencana Pengembangan SPALD-T Skala Permukiman Tahun 2033-2017

\begin{tabular}{|c|c|c|c|c|c|}
\hline \multirow[t]{2}{*}{ No } & \multicolumn{3}{|c|}{ Daerah Layanan } & \multirow[t]{2}{*}{ Unit } & \multirow{2}{*}{$\begin{array}{c}\text { Jumlah } \\
\text { Pelanggan (jiwa) }\end{array}$} \\
\hline & Kecamatan & & Desa/Kelurahan & & \\
\hline \multirow[t]{2}{*}{1} & Baki & 1 & $\begin{array}{l}\text { Bentakan, } \\
\text { Gedongan, Jetis, } \\
\text { Mancasan, Menuran, } \\
\text { Ngrombo }\end{array}$ & 1 & 10000 \\
\hline & & 2 & $\begin{array}{l}\text { Waru, Jati } \\
\text { (Kecamatan Gatak), } \\
\text { Trosemi (Kecamatan } \\
\text { Gatak) }\end{array}$ & 1 & 4500 \\
\hline \multirow[t]{2}{*}{2} & Bendosari & 1 & Mulur & 1 & 400 \\
\hline & & 2 & Toriyo dan Jombor & 1 & 6000 \\
\hline
\end{tabular}




\begin{tabular}{|c|c|c|c|c|c|}
\hline \multirow[t]{2}{*}{ No } & \multicolumn{3}{|c|}{ Daerah Layanan } & \multirow[t]{2}{*}{ Unit } & \multirow{2}{*}{$\begin{array}{c}\text { Jumlah } \\
\text { Pelanggan (jiwa) }\end{array}$} \\
\hline & Kecamatan & & Desa/Kelurahan & & \\
\hline 3 & Gatak & 1 & $\begin{array}{l}\text { Blimbing, Kagokan, } \\
\text { Klaseman, } \\
\text { Sanggung, Tempel, } \\
\text { sebaqian Luwang }\end{array}$ & 1 & 7000 \\
\hline \multirow[t]{2}{*}{4} & Mojolaban & $\begin{array}{l}1 \\
2\end{array}$ & $\begin{array}{l}\text { Bekonang } \\
\text { Demakan }\end{array}$ & $\begin{array}{l}1 \\
1\end{array}$ & $\begin{array}{l}400 \\
400\end{array}$ \\
\hline & & 3 & Triyagan & 1 & 400 \\
\hline \multirow[t]{2}{*}{5} & Polokarto & 1 & $\begin{array}{l}\text { Bugel, Karangwuni, } \\
\text { Ngombakan }\end{array}$ & 1 & 7000 \\
\hline & & 2 & Pranan & 1 & 400 \\
\hline \multirow[t]{6}{*}{6} & Sukoharjo & 1 & Bulakan & 1 & 600 \\
\hline & & 2 & Combongan & 1 & 400 \\
\hline & & 3 & Jetis dan Sukoharjo & 1 & 8500 \\
\hline & & 4 & Joho & 1 & 600 \\
\hline & & 5 & Kenep & 1 & 400 \\
\hline & & 6 & Mandan & 1 & 400 \\
\hline 7 & Tawangsari & 1 & Watubonang & 1 & 400 \\
\hline 8 & Weru & 1 & Tawang & 1 & 400 \\
\hline
\end{tabular}

Pada rencana pengembangan SPALD$T$ skala permukiman tahun 2032-2037 terdapat 6 IPAL permukiman skala besar, yaitu di 2 buah di Kecamatan Baki, masingmasing 1 buah di Kecamatan Bendosari, Gatak, Polokarto dan Kecamatan Sukoharjo. Lokasi IPAL Permukiman di Kecamatan Baki yang pertama dapat di tempatkan di Desa Ngrombo dengan elevasi sekitar $93 \mathrm{mdpl}$ dengan daerah pelayanan di Kecamatan Baki. Daerah yang akan dilayani oleh lokasi IPAL Permukiman Ngrumbo adalah Desa Bentakan, Gedongan, Jetis, Mancasan, Menuran, dan Ngrombo. Elevasi pada ujung daerah pelayanan adalah sekitar 109 mdpl, jika melihat rencana lokasi IPAL pada elevasi $93 \mathrm{mdpl}$ dan elevasi daerah pelayanan maka penyaluran air limbah dapat dilakukan secara gravitasi.

Lokasi IPAL Permukiman di Kecamatan Baki yang kedua dapat di tempatkan di Desa Waru dengan elevasi sekitar 108 mdpl dengan daerah pelayanan di Kecamatan Gatak dan Kecamatan Baki. Daerah yang akan dilayani oleh lokasi IPAL Permukiman Waru adalah Desa Waru yang berada di Kecamatan Baki dan Desa Jati serta Trosemi yang berada di Kecamatan Gatak. Elevasi pada ujung daerah pelayanan adalah sekitar $120 \mathrm{mdpl}$ sehingga penyaluran air limbah dapat dilakukan dengan cara gravitasi.

Lokasi IPAL Permukiman di Kecamatan Bendosari dapat di tempatkan di Desa
Jombor dengan elevasi sekitar 99 mdpl dengan seluruh daerah pelayanan berlokasi di Kecamatan Bendosari. Daerah yang akan dilayani oleh Lokasi IPAL Permukiman Jombor adalah Desa Toriyo dan Jombor. Elavasi pada ujung daerah pelayanan adalah sekitar $105 \mathrm{mdpl}$, sehingga penyaluran air limbah dapat dilakukan dengan cara gravitasi.

Lokasi IPAL Permukiman di Kecamatan Gatak dapat di tempatkan di Desa Blimbing dengan elevasi sekitar 120 mdpl dengan seluruh daerah pelayanan yang berlokasi di Kecamatan Gatak. Daerah yang akan dilayani oleh Lokasi IPAL Permukiman Blimbing adalah Desa Blimbing, Kagokan, Klaseman, Sanggung, Tempel, sebagian Luwang. Elavasi pada ujung daerah pelayanan adalah sekitar 139 dan 144 mdpl, sehingga penyaluran air limbah dapat dilakukan dengan cara gravitasi.

Lokasi IPAL Permukiman di Kecamatan Polokarto dapat di tempatkan di Desa Karangwuni dengan elevasi sekitar $95 \mathrm{mdpl}$ dengan seluruh daerah pelayanan berlokasi di Kecamatan Polokarto. Daerah yang akan dilayani oleh Lokasi IPAL Permukiman Karangwuni adalah Desa Bugel, Karangwuni, dan Ngombakan. Elavasi pada ujung daerah pelayanan adalah sekitar 105 mdpl, sehingga penyaluran air limbah dapat dilakukan dengan cara gravitasi.

Lokasi IPAL Permukiman di Kecamatan Sukoharjo dapat di tempatkan di Desa 
Sukoharjo dengan elevasi sekitar $96 \mathrm{mdpl}$ dengan seluruh daerah pelayanan berlokasi di Kecamatan Sukoharjo. Daerah yang akan dilayani oleh Lokasi IPAL Permukiman Sukoharjo adalah Desa Jetis dan Sukoharjo. Elavasi pada ujung daerah pelayanan adalah sekitar $103 \mathrm{mdpl}$, sehingga penyaluran air limbah dapat dilakukan dengan cara gravitasi.

\section{Kesimpulan}

Pengelolaan air limbah domestik di Kabupaten Sukoharjo dibagi menjadi dua, yaitu SPALD-Terpusat dan SPALDSetempat. Untuk peningkatan pelayanan pada sistem setempat, pada pengangkutan lumpur tinja maka dilakukan penambahan armada pengangkut berupa truk dan motor roda tiga penyedot tinja. Dalam pengolahan lumpur tinja, dikembangkan menjadi 3 (tiga) daerah pelayanan IPLT yang dibangun secara bertahap. Tahap pertama yaitu optimalisasi IPLT Eksisting (IPLT Mojorejo), tahap kedua yaitu pembangunan IPLT di Desa Bekonang Kecamatan Mojolaban, dan tahap ketiga pembangunan IPLT di Desa Grajegan Kecamatan Tawangsari. IPLT direncanakan dapat melayani sekitar $70 \%$ penduduk perkotaan. Untuk perencanaan sistem terpusat, direncanakan IPAL Permukiman dan IPAL Perkotaan dengan rencana pelayanan sebesar $20 \%$ penduduk perkotaan Kabupaten Sukoharjo.

\section{Daftar Pustaka}

Anonimous. 2006. Materi Teknis Tata Cara Pemilihan Lokasi IPA/IPLT. Departemen Pekerjaan Umum. Jakarta.

Anonimous. 2016. Peraturan Menteri Lingkungan Hidup dan Kehutanan No. 68 Tahun 2016 tentang Baku Mutu Air Limbah Domestik. Kementerian Lingkungan Hidup dan Kehutanan.

Anonimous. 2016. Pedoman Penyusunan Rencana Induk Sistem Pengelolaan Air Limbah. Kementrian Pekerjaan Umum dan Perumahan Rakyat.

Anonimous. 2017. Peraturan Menteri Pekerjaan Umum dan Perumahan Rakyat Nomor 04 Tahun 2017
Tentang Penyelenggaraan Sistem Pengelolaan Air Limbah Domestik. Kementerian Pekerjaan Umum dan Perumahan Rakyat.

Anonimous. 2001. Peraturan Pemerintah Republik Indonesia Nomor 82 tahun 2001 tentang Pengelolaan Kualitas Air dan Pengendalian Pencemaran Air.

Anonimous. 2017. Sistem Informasi IPAL Komunal Kabupaten Sukoharjo. https://siipalsukoharjo.com/ akses tanggal 27 Februari 2018.

Babbit, 1969. Sewage and Sewarage Treatment Plant. McGraw Hill. New York.

Hardjosuprapto dan Masduki, M., 2000. Penyaluran Air Buangan (PAB) Vol. 2. ITB. Bandung

Hindarko, 2003. Mengolah Air Limbah Supaya Tidak Mencemari Orang Lain. ESHA Seri Lingkungan Hidup. Jakarta.

Mara, D., 1976. Sewage Treatment in Hot Climate. John Wiley \& Sons. New York.

Soemirat, J., 1994. Kesehatan Lingkungan. Gajahmada University Press. Yogyakarta

Sugiharto, 2005. Dasar-dasar Pengelolaan Air Limbah. UI Press. Jakarta.

Sunu, P., 2001. Melindungi Lingkungan dengan Menerapkan ISO 14001. Gramedia Widiasarana Indonesia. Jakarta.

Suriwiria, U., 1996. Mikrobiologi Air dan Dasar-Dasar Pengolahan Air. Penerbit Alumni. Bandung.

Tchobanoglous, G. 1981. Wastewater Engineering: Collection and Pumping of Wastewater. McGraw Hill. New York.

Tchobanoglous, G., Burton, F. L., dan Stensel, H. D. 2003. Wastewater Engineering: Treatment and Reuse. 4th edition ed. Metcalf and Eddy Inc. New York. 